\title{
Comparative Analysis of Removal of Crude Oil and Some Refined Petroleum Products From The Environment Using Rice Husk: Adsorption Isotherm and Kinetic Studies
}

\author{
H. I. Kelle \\ Department of Pure and Applied Sciences, National Open University of Nigeria \\ [E-mail: henriettachima@yahoo.com; r: +2348037821945]
}

\begin{abstract}
Rice husk a low cost agricultural waste was assessed for its efficiency as an oil spill sorbent by comparing its oil (crude oil, diesel and kerosene) uptake with that of a standard conventional synthetic sorbent mat used in oil spill clean-up. The sorption process of crude oil, diesel and kerosene onto rice husk and the standard was studied using Langmuir, Freundlich, Elovich, Temkin and Dubinin Radushkevich adsorption models while the sorption kinetics was studied using Lagergren pseudo-firstorder, pseudo-second-order, intraparticle diffusion and liquid film diffusion models. Suitable environmental applicability of both sorbents was also studied. The result of the study shows that rice husk sorbed $3.30 \pm 0.23 \mathrm{~g}$ of crude oil, $2.50 \pm 0.81 \mathrm{~g}$ of diesel and $1.95 \pm 0.72 \mathrm{~g}$ of kerosene per unit mass while the standard sorbed $11.50 \pm 0.54 \mathrm{~g}$ of crude oil, $10.34 \pm 0.77 \mathrm{~g}$ of diesel and $8.20 \pm 0.93 \mathrm{~g}$ of kerosene per unit mass. About $2.46 \pm 0.17 \mathrm{~g}$ of sorbed crude oil, $1.60 \pm 0.64 \mathrm{~g}$ of sorbed diesel and $1.57 \pm$ $0.11 \mathrm{~g}$ of sorbedkerosene were recovered from a unit mass of rice husk, while, $9.67 \pm 0.36 \mathrm{~g}$ of sorbed crude oil, $8.40 \pm 0.95 \mathrm{~g}$ of sorbed diesel and $6.50 \pm 0.49 \mathrm{~g}$ of sorbed kerosene were recovered from a unit mass of synthetic sorbent mat. The amount of the sorbed oils retained by a unit mass of rice husk is about $0.84 \pm 0.22 \mathrm{~g}$ of crude oil ( $25 \%$ of sorbed crude oil), $0.90 \pm 0.97 \mathrm{~g}$ of diesel ( $36 \%$ of sorbed diesel), and $0.38 \pm 0.90 \mathrm{~g}$ of kerosene ( $20 \%$ of sorbed kerosene), while, $1.83 \pm 0.33 \mathrm{~g}$ of crude oil (15\% of sorbed crude oil), $1.94 \pm 0.97 \mathrm{~g}$ of diesel ( $19 \%$ of sorbed diesel) and $1.70 \pm 0.89 \mathrm{~g}$ of kerosene $(20 \%$ of sorbed kerosene) were retained by a unit mass of synthetic sorbent mat. The result of the study indicates that the standard is a better sorbent for oil removal than rice husk. Rice husk has the ability to retain sorbed oil which makes it a good sorbent when oil recovery is not required, but disposal. The sorption process for both sorbents follows the Langmuir isotherm. Intraparticle diffusion model and liquid film diffusion model were parts of the rate determining steps of the sorption process of the oils onto rice husk and the standard.
\end{abstract}

Keywords: Rice husk, adsorption isotherm, adsorption kinetics, crude oil, refined petroleum products.

\section{INTRODUCTION}

Oil is an important commodity in the world because of its many applications which include energy source for homes, transportation, industries and source of raw materials for chemical industries especially those involved in production of carbon-based products (Testa and Jacobs, 2013; Kent, 2010). Due to its wide application, crude oil and its refined products are in demand, necessitating exploration, exploitation, refining of crude oil and distribution of refined petroleum products. The processes involved in search for oil beneath the earth surface, extraction of oil, movement of crude oil through pipelines from production wells to refineries, storage of refined petroleum products and transportation of refined petroleum products to consumers can lead to oil spill in the environment through such instances as; release of crude oil from offshore platforms, drilling rigs and wells, leaks from pipelines and storage tanks and accidents during transportation involving tankers, ships conveying oil E.T.C. (Gerard, 2016;Wang, 2014).

Oil spill can have detrimental effect on the environment which includes damage to vegetation, oiling of beaches and in some cases fire outbreak, dead wildlife, oil covered marshlands and contaminated water chief among them (Fingas, 2010). Venn-Watson et al,(2015) in their study to assess potential contributing factors and causes of deaths for 
unusual mortality event involving primarily bottlenose dolphins (Tursiops truncates) in the Gulf of Mexico from June 2010 through December 2012, their findings linked the increased death of the dolphins to chronic adrenal gland and lung diseases caused by exposure of the dolphins to elevated petroleum compounds present in coastal Gulf of Mexico waters during and after the Deepwater Horizon oil spill. Similarly,Hester et al, (2016)evaluated the impact of the spill on coastal wetland vegetation in different habitat types in the northern Gulf of Mexico, and documented significant injury to plant production, elevated chlorosis of plant tissue and reduction in cover and peak standing crop, and health of Louisiana salt marshes exposed to the spill. In Nigeria, oil spill incidents have occurred in various parts and at different times in the oil producing Niger Delta region where several oil industries is located(Kadafar, 2012). The impacts of these spills resulted to destruction of wildlife and biodiversity, loss of fertile soil, pollution of air and drinking water, degradation of farmland and damage to aquatic ecosystem (Kadafar, 2012).

Due to the adverse effect of oil spill on the environment efforts are being made to clean oil spills once it happens. Oil spill clean-up makes use of such facilities as booms for oil containment, sorbents which can be natural or synthetic and a host of other methods (Fingas, 2010). Research has focused on agricultural based sorbents because of their biodegradability and low cost (Deschamps et al, 2003; Choi and Cloud, 1992). Some natural sorbents have been reported to show good oil sorption capacity and in some cases higher oil sorption capacity than synthetic sorbents. Lim and Huang (2007) examined a hollow cellulosic kapok fibre, and reported the fiber oil sorption capacity was approximately $1.5-2.0$ times greater than that of polypropylene mat a commonly used synthetic sorbent in oil spill cleanup. Similarly, the cellulosic fibers milkweed (Asciepias) and cotton were shown to sorb significantly higher amounts of crude oil than polypropylene fiber and polypropylene web (Choi and Cloud, 1992).Nduka et al,
(2008),Paulauskieneet al, (2014) and Dong et al, (2015) reported good oil sorption capacity by goat hair, peat and cattail/kapok blend respectively.

Rice is the primary staple food for more than half of the world's population, with Asia representing the largest producing and consuming region (FAO Statistical Yearbook, 2013). According to available statistics, about 7 million metric tonnes of rice is consumed annually in Nigeria, while local production now stands at about 3.9 million metrics tons. Rice husks is a major by-product of the rice milling industry (Mansaray and Ghaly, 1997), it is the natural shealths that form on the rice grain during their growth and are removed during refining, with little commercial value (Omatolaet al., 2009). For every $1000 \mathrm{~kg}$ of milled paddy, about $200 \mathrm{~kg}(20 \%)$ of husk is produced (Siddique, 2001). Local paddy production by Nigerian farmers has increased by about two million tonnes in the last two years (This Day, 2017). This generates quite enormous agricultural waste much of which is either burnt or dumped as waste (Omatola et al., 2009). This study aims to investigate the possibility of managing rice husk waste by comparing its oil spill mopping efficiency with a conventional synthetic sorbent.

\section{MATERIALS AND METHODS Collection of materials}

Rice husk was obtained from a rice mill in Awgu, Enugu state, Nigeria, while conventional synthetic sorbent mat made of polyhydrocarbons was obtained from Department of Oil Spill Remediation, Shell Petroleum Development Company, Port Harcourt, Rivers state, Nigeria. Crude oil was obtained from Shell Petroleum Development Company, Warri, Delta state, Nigeria while diesel and kerosenewere purchased from Total filling station, Asaba, Delta State, Nigeria.

\section{FTIR spectroscopic analysis of conventional synthetic sorbent mat}

The functional groups present in the synthetic sorbent were determined by FTIR spectroscopy. The FTIR analysis was carried 
out using SHIMADZU FTIR-8400S spectrophotometer with a $\mathrm{NaCl}$ cell. The sample was ground into fine powder and spread uniformly in between two $\mathrm{NaCl}$ based cells. The cells were fixed into the machine and an incident ray of light passed through it. The FTIR spectrophotometer was operated under the following conditions; interferometer: Michelson type with $30^{\circ}$ incident angle, dynamic alignment, sealed desiccated, optical system: single beam optics, beam splitter: germaniumcoated $\mathrm{HBr}$ plate, light source: high brightness ceramic, detector: temperature controlled high sensitivity detector (DLATGS detector), S/N ratio: greater than 20,000: 1 (KRS-5 window), $4 \mathrm{~cm}^{-1}, 1$ minute, $2200 \mathrm{~cm}^{-1}$, P-P, wave number: $7,800 \mathrm{~cm}^{-1}-350 \mathrm{~cm}^{-1}$, resolution: $0.85,1,2,4,8$, $16 \mathrm{~cm}^{-1}$, mirror speed: 3 steps; 2.8, 5 , $9 \mathrm{~mm} / \mathrm{sec}$, data sampling: He-Ne laser, sample.

\section{Preparation of sample}

Rice husk was washed with water, strained and allowed to dry under the sun for 2 weeks. It was milled with a mechanical blender and sieved through a sieve of $0.05 \mathrm{~mm}$, packed into opaque polythene bags before commencement of the experiment.

Determination of equilibrium sorption capacity, oil recovery and oil retention capacities of rice husk and synthetic sorbent mat.

Five grams each of rice husk and synthetic sorbent mat were weighed into different $2 \mathrm{dm}^{3}$ beaker containing $1 \mathrm{dm}^{3}$ of crude oil, diesel and kerosene sorbates, whose weight had been predetermined, and left for a required contact time at $28^{\circ} \mathrm{C}$. The weights of the sorbates are $801 \mathrm{~g}, 768 \mathrm{~g}$ and $760 \mathrm{~g}$ respectively. The contact times used in this study ranged from 10 to 100 minutes at 10 minutes interval after which the content in the beaker was passed through a sieve of $0.03 \mathrm{~mm}$ into another pre-cleaned and pre-weighed $2 \mathrm{dm}^{3}$ beaker and allowed to drain. The weight of the $2 \mathrm{dm}^{3}$ beaker containing unsorbed sorbate was weighed, after which, the weight of the $2 \mathrm{dm}^{3}$ beaker was subtracted from it to obtain the weight of unsorbed sorbate.
The amount of sorbate sorbed onto a unit mass of rice husk/synthetic sorbent mat was calculated from:

$\mathrm{q}=\frac{\text { Initial weight of oil }(g)-\text { Final weight of oil }(g)}{M}$

Where $q=$ Amount of sorbate sorbed onto a unit mass of rice husk/synthetic sorbent.

$\mathrm{M}=$ Mass of sorbent in grams $(\mathrm{g})$.

The amount of each sorbate recovered from each sorbent was determined by removing the sorbent from the sieve, weighing it and afterwards subjecting it to pressing using a carver hydraulic press, Model $M$, serial No. 12000 - 137, operated at a compressive force of $25 \mathrm{~N}$, for five minutes, at $28 \circ \mathrm{C}$. After pressing, the sorbent was re- weighed; the weight of sorbate recovered was determined by weight difference.

The amount of sorbate recovered per unit mass of sorbent was determined from the expression:

$q=\frac{\text { Initial weight of oil-Final weight of oil }}{M}$

Where $q=$ Amount of sorbate recovered from a unit mass of rice husk/synthetic sorbent.

$M=$ Mass of sorbent in grams $(\mathrm{g})$.

The amount of sorbate retained per unit mass of sorbent was obtained from the expression:

$q=$ Quantity of sorbate sorbed per unit mass of sorbent - Quantity of sorbate recovered per unit mass of sorbent.

The experiment was performed in triplicate, the average and standard deviation was calculated and used.

\section{Verification of adsorption process of crude} oil, diesel and kerosene onto rice husk/synthetic sorbent mat using adsorption isotherm

Adsorption process of the sorbates onto rice husk and synthetic sorbent mat was done using the linearized form of Langmuir, Freundlich, Elovich, Temkin and Dubinin - Radushkevich adsorption models. Five different initial concentrations (measured in volume and 
weight) of each sorbate; $0.5 \mathrm{dm}^{3}, 0.75 \mathrm{dm}^{3}$, $1.00 \mathrm{dm}^{3}, 1.25 \mathrm{dm}^{3}$ and $1.5 \mathrm{dm}^{3}$ were used for the experiment. The sorbate - sorbent system contact time was 80 minutes. The mean of triplicate determination was thereafter calculated.

The experimental dataequilibrium adsorption capacity $\left(\mathrm{q}_{\mathrm{e}}\right)$ and equilibrium concentration $\mathrm{C}_{\mathrm{e}}$ ) obtained were fitted into Freundlich, Langmuir, Elovich, Temkin and Dubinin-Radushkevich adsorption models.

The Langmuir equation may be written as:

$q_{e}=\frac{q_{m} b C_{e}}{1+b C_{e}}$

Where:

$q_{e}$ is the amount of solute adsorbed per unit weight of sorbent at equilibrium $(\mathrm{mg} / \mathrm{g})$

$C_{e}$ isthe equilibrium concentration of the solute in the bulk solution ( $\mathrm{mg} \mathrm{L}^{-1}$ )

$q_{m}$ is the maximumadsorption capacity $(\mathrm{mg} / \mathrm{g})$ $b$ is the constant related to the energy of adsorption and temperature, and affinity between

the sorbent and sorbate (Langmuir, 1916).

Langmuir isotherm model can be linearized to five different forms, out of which the forms $\frac{1}{q_{e}}=$ $\frac{1}{b q_{m}} \frac{1}{C_{e}}+\frac{1}{q_{m}}$ (plot $\frac{1}{q_{e}}$ vs. $\frac{1}{C_{e}}$ ) and $\frac{C_{e}}{q_{e}}=\frac{1}{q_{m C_{e}}}+\frac{1}{q_{m b}}$ (plot $\frac{C_{e}}{q_{e}}$ vs $C_{e}$ ) are the most frequently used by several researchers because of the minimized deviations from the fitted equation resulting in the best error distribution. A plot of $\frac{C_{e}}{q_{e}}$ against $C_{e}$ produces a linear graph with slope $=\frac{1}{q_{m}}$ and intercept $\frac{1}{k_{a q_{m}}}$ and a plot of $\frac{1}{q_{e}}$ versus $\frac{1}{C_{e}}$ gives a linear graph with slope $=\frac{1}{K_{a q_{m}}}$ and intercept $\frac{1}{q_{m}}$. Both linear forms were applied to the experimental data obtained.

The Freundlich equation canbe written as: $q_{e}=\mathrm{KfCe}^{1 / \mathrm{n}}$

$K_{f}$ is a constant indicative of the relative adsorption capacity of the adsorbent $\mathrm{mg}(1-(1 / \mathrm{n}))$
$\mathrm{L}^{1 / n g-1}$ and $\mathrm{n}$ is a constant indicative of the intensity of the adsorption (Freundlich, 1906).

The linear model of Freundlich isotherm can be expressed logarithmically as:

$\log q_{e}={ }_{n}^{1} \log C_{e}+\log K_{f}$

Or

$\ln q_{e}=\ln K_{f}+\frac{1}{n} \ln C_{e}$. Both linear forms were applied to the experimental data obtained.

The values of parameters $K_{f}$ and $1 / n$ can be determined from the intercept and slope of the plot $\log q_{e}$ against $\log C_{e}$ or $\ln q_{e}$ against $\ln C_{e}$ (Hamdaoui and Naffrechoux, 2007; WeiHong et al, 2013; Piccinet al, 2011).

Temkinisotherm model is given by:

$q_{e}=\frac{R T}{b} \ln K_{T}+\frac{R T}{b} \ln C_{e} \quad$ (Piccinet al, 2011).

where $\mathrm{K}_{\mathrm{T}}$ is the equilibrium binding constant $(\mathrm{L}$ $\mathrm{mol}^{-1}$ ) corresponding to the maximum binding energy, $b$ is related to the adsorption heat, $R$ is the universal gas constant (8.314 $\left.\mathrm{J} \mathrm{K}^{11} \mathrm{~mol}^{\prime 1}\right)$ and $T$ is the temperature $(K)$. From the linear plot $q_{e}$ against $\ln C_{e}$ the slope $\frac{R T}{B}$ and intercept $\left(R T \ln k_{T}\right) \mathrm{b}$ can be determined.

Dubinin-Radushkevich isotherm model is represented as:

$q_{e}=q_{D} \exp \left(-B_{D}\left[R T \ln \left(1+1 / C_{e}\right)\right]^{2}\right.$ Hong et al, 2013; Piccinet al, 2011; Igwe and Abia, 2007).

Where $q_{D}$ is the theoretical adsorption capacity $(\mathrm{mg} / \mathrm{g}), B_{D}$ is a constant related to adsorption energy, $R$ is gas constant $(\mathrm{KJ} / \mathrm{mol} . \mathrm{K})$, Tis temperature $(\mathrm{K})$.

The linear form of Dubinin-Radushkevich isotherm model is given as:

$\ln q_{e}=\ln q_{D}-2 B_{D} R T \ln \left(1+1 / C_{e}\right)$

The plot oflnq $q_{e}$ against $R T \ln \left(1+1 / C_{e}\right)$ yields a straight line, the values of $q_{D}$ and $B_{D}$ can becalculated from the intercept and slope. The equation defining the Elovichmodel is expressed by the equation:

$\frac{q_{e}}{q_{m}}=K_{E} C_{E} \exp \left({ }^{q_{e}} / q_{m}\right) \quad$ (Elovich, 1962).

where $K_{E}$ is the Elovich equilibrium constant (Lmg-1) and $q_{m}$ is the Elovich maximum 
adsorptioncapacity $\left(\mathrm{mg}^{-1}\right)$.If the adsorption obeys Elovichequation, Elovich maximum adsorption capacity and Elovich constant can be calculated from the slopes and the intercepts of the linear plotln $\left(q_{e} C_{e}\right)$ versus $q_{e}$.

\section{Kinetic Studies}

Lagergren pseudo-first-order, pseudo-secondorder, intraparticle diffusion and liquid film diffusion kinetic models were used for experimental data analysesto investigate the rate and mechanism of sorption process of the sorbate - sorbent system under study.

The linearized pseudo-first-order kinetic model, which is also known as the Lagergren equation, can beexpressed as:

$\ln \left(q_{e}-q_{t}\right)=\ln q_{e}-k_{1} t$

where $q_{\mathrm{t}}$ and $q_{\mathrm{e}}$ are the amounts of sorbatesorbed at time $t(\mathrm{~s})$ and equilibrium, respectively, in $\mathrm{mg} / \mathrm{g} . k_{1}$ is the pseudo-firstorder rate constant $\left(\mathrm{s}^{-1}\right)$ (Dawodu and Akpomie, 2014). The slope and intercept of the plots of $\ln \left(q_{\mathrm{e}}-q_{\mathrm{t}}\right)$ as a function of $t$ were used to determine the rate constant and $q_{\mathrm{e}}$.

The linear form of pseudo - second order kinetic model is expressed as:

$\frac{t}{q_{t}}=\frac{1}{k_{2 q_{e}^{2}}^{2}}+\frac{t}{q_{e}}$

Where $k_{2}$ is the rate constant of the pseudosecond-order expression $\left(\mathrm{g} / \mathrm{mg} \mathrm{s}^{-1}\right)$. The $q_{\mathrm{e}}$ and $k_{2}$ values were calculated from the slope and intercept of the linear plot of $t / q_{t}$ as a function of the time $(t)$ (Ho and Mackay, 1998). The initial sorption rateh $\left.\left(\mathrm{mg} / \mathrm{g} \mathrm{s}^{-1}\right)\right)$ was calculated from the following equation:

$\mathrm{h}=\mathrm{K}_{2} \mathrm{q}_{\mathrm{e}}{ }^{2}$

The intraparticle diffusion model can be expressed as:

$q_{t}=k_{d} \cdot t^{1 / 2}+1$

whereq $t_{t}$ s the amount of solute sorbed at timet, $k_{d}$ is the intraparticle diffusion rate constant $\left(\mathrm{mg} / \mathrm{g} \mathrm{s}^{1 / 2}\right)$ and $I$ is the intercept (Weber and Morris, 1963). Plot of $q_{t}$ as a function of $t^{1 / 2}$ is linear if intraparticle diffusion occurs. The $k_{d}$ constant is obtained from the slope of the plot of $q_{\mathrm{t}}$ as a function of $t^{1 / 2}$.

The equation representing liquid film diffusion kinetics can be expressed as:

$\ln (1-F)=-k_{f d} \cdot t \ln (1-F)=-k f d \cdot t$

where $F$ is the fractional attainment of equilibrium $\left(F=q_{t} / q_{\mathrm{e}}\right)$ and $k_{\mathrm{fd}}$ is the rate constant (meq g ${ }^{-1} \mathrm{~s}^{1 / 2}$ )(Taffarel and Rubio, 2009). A plot of $\ln (1-F)$ as a function of $t$ is linear.

Determination of mopping ability of crude oil, diesel and kerosene displaced on wateronto rice husk/synthetic sorbent mat.

In order to determine suitable environment applicability of rice husk and synthetic sorbent mat, the experiment was repeated with crude oil, diesel and kerosene displaced on water. Onedm 3 of water was poured into a $2 \mathrm{dm}^{3}$ beaker and $0.5 \mathrm{dm}^{3}$ of sorbate was added. Five grams of rice husk/synthetic sorbent mat was added into the sorbate displaced on waterand left for 80 minutes. At the end of contact time, the sorbents were carefully separated from the sorbates displaced on water by passing it throughWhatman No. 1 filter paper fitted onto a glass funnel inserted into another $2 \mathrm{dm}^{3}$ beaker. Small amounts of sorbate which formed the boundary layer between water and the sorbate were not separated from water during the filtration, because oil will be lost. The sorbate was carefully removed using syringe and added to the filterate (sorbate) in the beaker. The volume and weight of separated water from sorbate was determined.

\section{RESULTS AND DISCUSSION}

The amount of the sorbates sorbed onto the sorbents is presented in Figure 1. The equilibrium sorption capacity of crude oil, diesel and kerosene onto rice huskwere observed as $3.30 \pm 0.23 \mathrm{~g}$ at 80 minutes, $2.50 \pm 0.81 \mathrm{~g}$ at 80 minutes and $1.95 \pm 0.72 \mathrm{~g}$ at 70 minutes respectively while that observed for synthetic sorbent mat was $11.50 \pm 0.54 \mathrm{~g}$ of crude oil at 30 minutes, $10.34 \pm 0.77 \mathrm{~g}$ of diesel at 60 minutes and $8.20 \pm 0.93 \mathrm{~g}$ of kerosene at 50 minutes. The result indicated that the synthetic sorbent had higher sorption capacity compared to rice husk. 
Adsorption is generally favoured by low temperature, high surface area and highly reactive sorbates and sorbents. Organic sorbates chemically bond to the sorbent if the sorbate and sorbent have mutually reactive moieties (Brown, 1983). Variety of different types of attractive forces between the sorbate and sorbent results in sorption and the extent oftheseintermolecular attractions depends on molecular chain length and on surface area available for interaction (Weneret al, 1991).

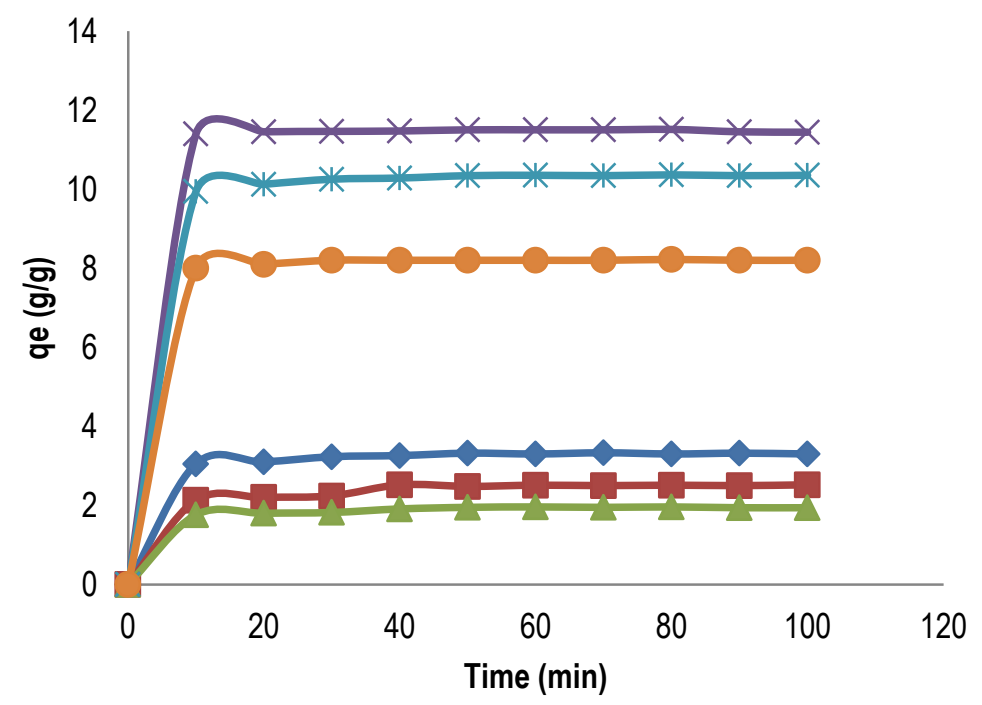

-Amount of crude oil sorbed onto a unit mass of rice husk (qe) against time

-Amount of diesel sorbed onto a unit mass of rice husk (qe) against time

- Amount of kerosene sorbed onto a unit mass of rice husk (qe) against time

$\leftarrow$ Amount of crude oil sorbed onto a unit mass of synthetic sorbent (qe) against time"

Figure 1: Amount of crude oil, diesel and kerosene sorbed onto a unit mass of rice husk/ synthetic sorbent against time.

The major polymer structures of rice husks are cellulose $(50 \%)$, lignin $(25-30 \%)$ and silica $(15-20$ $\%$ ) (Siddique, 2008). FTIR spectrum of the synthetic sorbent mat is presented in Figure 2, the prominent peaks indicates that it is a polyhydrocarbon: $829.42 \mathrm{~cm}^{-1}(\mathrm{~s}) \mathrm{C}-\mathrm{H}$ of alkene, $983.73 \mathrm{~cm}^{-1}(\mathrm{~s}) \mathrm{C}-\mathrm{H}$ of alkene, $1159.26 \mathrm{~cm}^{-1}$, (s) C-C of alkane, $1369.50 \mathrm{~cm}^{-1}(\mathrm{~s}) \mathrm{C}-\mathrm{H}$ of alkane , $1453.41 \mathrm{~cm}^{-1}(\mathrm{~s}) \mathrm{C}-\mathrm{H}$ of alkane, $2925.15 \mathrm{~cm}^{-1}(\mathrm{~s}) \mathrm{C}-\mathrm{H}$ of alkane.

The synthetic sorbent mat and the sorbates are composed mainly of hydrocarbons which suggest an enhanced sorbate - sorbent mutually reactive interaction when compared with rice husk polymer structure. This probably explains the more sorption capacity of the synthetic sorbent mat as observed.

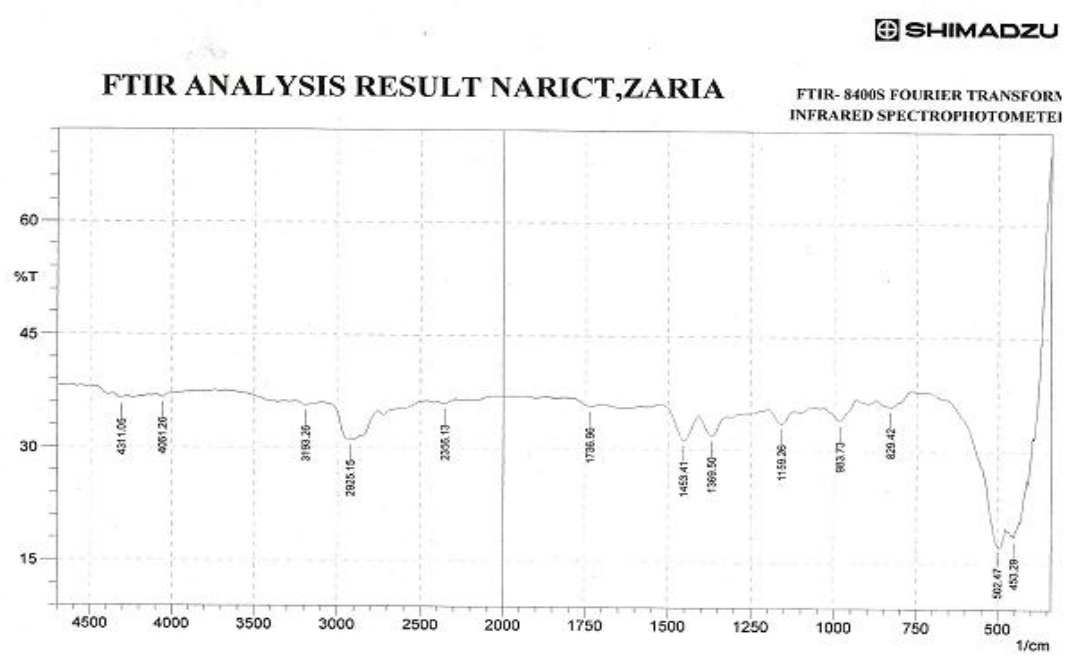

Figure 2: FTIR spectrum of synthetic sorbent. 
The result of the study shows that a time of about 80 minutes is required to attain equilibrium by rice husk, while, the synthetic sorbent attained equilibrium in a lesser time. This indicates the presence of large internal surface area and wide pore volume distribution in the standard which enabled faster oil uptake by the standard. Thesorption of the sorbates onto rice husk and the synthetic sorbent increased as the sorption time increased until equilibrium was attained because three consecutive mass transport steps are associated with the sorption of a solute from solution by a porous sorbent (Faust and Aly, 1983). First, the solute migrates through the solution to the external surface of the sorbent particles by molecular diffusion (film diffusion), followed by solute movement from particle surface to interior sites (pore diffusion) and

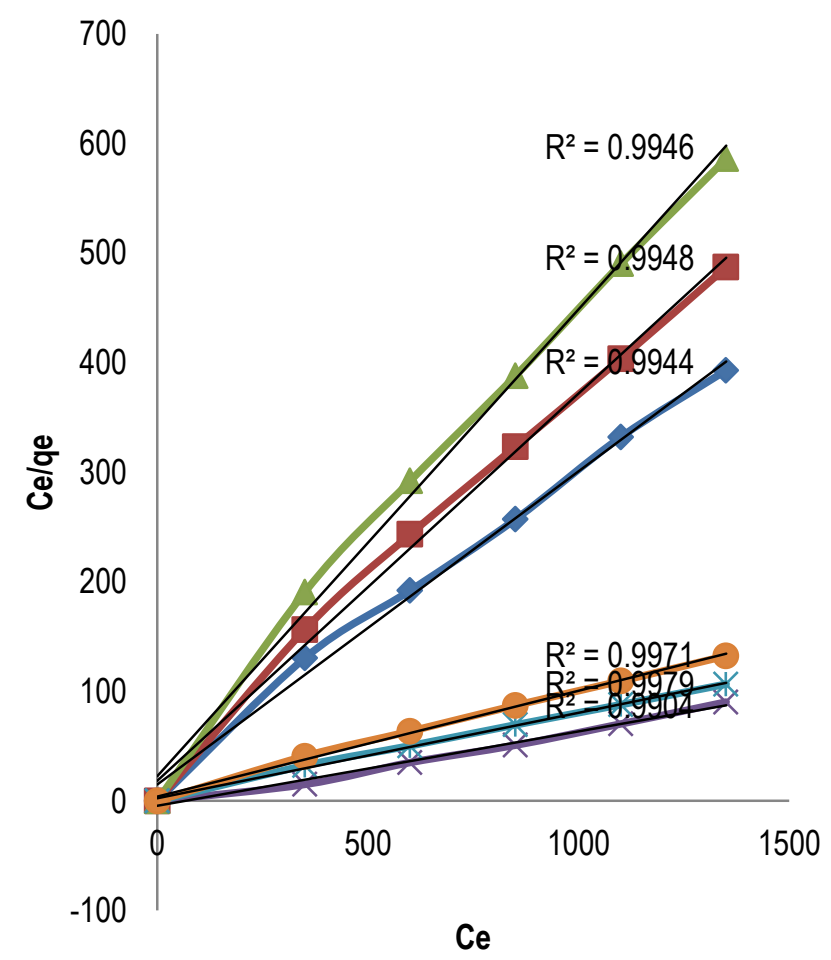

finally the solute absorbed onto these sites, this makes the sorption gradual.Result also indicates that sorption capacity in both sorbents increases with increase in viscousity of the sorbates as well as chain length.

\section{Adsorption isotherm studies}

Among the adsorption isotherms appliedto the experimental data to describe the adsorptionprocessthe linearized form $\mathrm{C}_{e} / \mathrm{q}_{\mathrm{e}}$ versus $\mathrm{C}_{e}$ of the Langmuir adsorption isotherm produced the best fit isotherm (0.99) for the sorption of the sorbates onto the sorbents (Figure 3).This implies that sorbate - sorbent interaction is a monolayer process, i. e. onesorbate molecule is adsorbed on a layer of adsorbent with no further interaction between the adsorbed molecules.

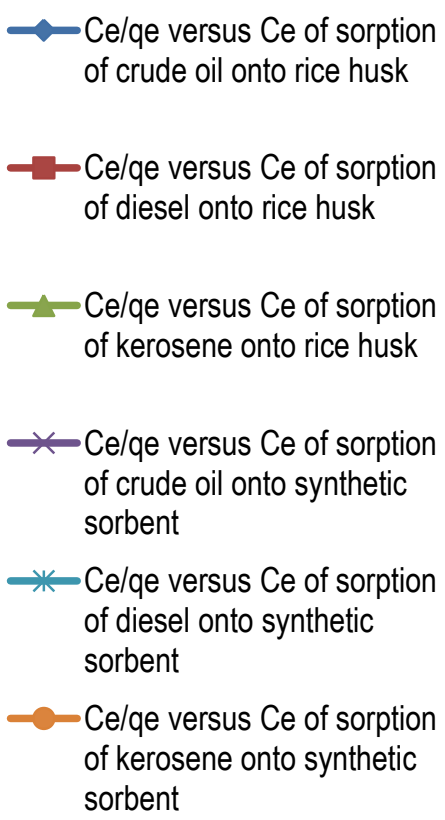

- Ce/qe versus Ce of sorption

Ce/qe versus $\mathrm{Ce}$ of sorption of diesel onto rice husk of kerosene onto rice husk

$*$ Celqe versus Ce of sorption of crude oil onto synthetic of diesel onto synthetic Ce/qe versus Ce of sorption of kerosene onto synthetic

Figure 3: Langmuir Ce/qe versus Ceplot of sorption of crude oil, diesel and kerosene onto rice husk/synthetic sorbent.

Sorbents can be compared by their respective maximum adsorption capacity $\mathrm{q}_{\mathrm{m}}$ and $\mathrm{b}$ values obtained from the Langmuir equation (Volesky, 2004). The maximum adsorption capacity $q_{m}$ is obtained from the isotherm model while $q_{e}$ is the equilibrium adsorption capacity obtained from experiment (Jing, 2010). qmcan be interpreted as the total number of binding sites that are available for sorption while qeas the number of sites actually occupied by the sorbate at the equilibrium concentration $\mathrm{C}_{e}$ (Volesky, 2004). The constant $b$ and $q_{m}$ are obtained from the slope and interception of the plot as in Table 1. The $b$ values for both rice 
husk and synthetic sorbent mat are 1.00 . This implies that both sorbents have same degree of affinityfor crude oil, diesel and kerosene. The calculated maximum adsorption capacity value $\left(q_{m}\right)$ of rice husk and synthetic sorbent mat are slightly higher than their experimental equilibrium adsorption capacity value (Table 1). This further shows that Langmuir isotherm provides better fit to the experimental values and can be used to verify the adsorption of crude oil, diesel and kerosene onto rice husk and synthetic sorbent mat. The higher $q_{m}$ values of synthetic sorbent mat for the sorbates compared with those of rice husk indicates that synthetic sorbent mat has more total number of binding sites than the rice husk, which implies that, the synthetic sorbent mat has a larger surface area and higher oil uptake than rice husk. The $q_{m}$ shows that the synthetic sorbent mat is a better sorbent than rice husk.

\section{Oil recovery and retention characteristics}

The quantity of oils recovered from and retained by rice husk and synthetic sorbent mat are shown in Figures 4 and 5 . About $2.46 \pm 0.17 \mathrm{~g}$ of crude oil, $1.60 \pm 0.64 \mathrm{~g}$ of diesel and $1.57 \pm$
$0.11 \mathrm{~g}$ of kerosene were recovered from a unit mass of rice husk, while, $9.67 \pm 0.36 \mathrm{~g}$ of crude oil, $8.40 \pm 0.95 \mathrm{~g}$ of diesel and $6.50 \pm 0.49 \mathrm{~g}$ of kerosene were recovered from a unit mass of synthetic sorbent mat. The higher amount of oil recovered from the standard sorbent matrial may be attributed to the porous structure of large internal surface area and wide pore volume distribution,which is not the case with rice husk. More sorbates diffuse into the pores and effuse easily than in rice husk. The amount of oils retained by rice husk is about $0.84 \pm$ $0.22 \mathrm{~g}$ of crude oil $(25 \%), 0.90 \pm 0.97 \mathrm{~g}$ of diesel $(36 \%)$, and $0.38 \pm 0.90 \mathrm{~g}$ of kerosene (20\%), while, $1.83 \pm 0.33 \mathrm{~g}$ of crude oil (15\%), 1.94 \pm $0.97 \mathrm{~g}$ of diesel $(19 \%)$ and $1.70 \pm 0.89 \mathrm{~g}$ of kerosene $(20 \%)$ were retained by synthetic sorbent mat. Critical examination of these values reveals that rice husk retained more of the sorbed oils than the synthetic sorbent mat. This indicates that rice husk is suitable for removal of the sorbatessince one of the features of a good sorbent is high degree of oil retention (Hoskin, 2006; Volesky, 2004; Choi and Cloud, 1992), especially when clean-up does not require recovery but disposal.

Table 1: Parameters of Langmuir isotherm $\left(\mathrm{C}_{\mathrm{e}} / \mathrm{q}_{\mathrm{e}} \mathrm{vs} \mathrm{C}_{\mathrm{e}}\right)$ and equilibrium sorption capacity $\left(\mathrm{q}_{\mathrm{e}}\right)$ of crude oil, diesel and kerosene onto rice husk and synthetic sorbent.

\begin{tabular}{llll}
\hline Sorption type & $\mathbf{b}\left(\mathrm{L} \mathrm{g}^{-1}\right)$ & $\boldsymbol{q}_{\boldsymbol{m}}\left(\mathrm{g} \mathrm{g}^{-1}\right)$ & $\mathrm{r}^{2}$ \\
\hline Crude oil - rice husk & 1.00 & 3.38 & 0.9944 \\
Diesel - rice husk & 1.00 & 2.94 & 0.9948 \\
Kerosene - rice husk & 1.00 & 2.00 & 0.9946 \\
Crude oil - synthetic sorbent mat & 1.00 & 11.62 & 0.9904 \\
Diesel - synthetic sorbent mat & 1.00 & 10.52 & 0.9979 \\
Kerosene - synthetic sorbent mat & 1.00 & 8.40 & 0.9971 \\
\end{tabular}



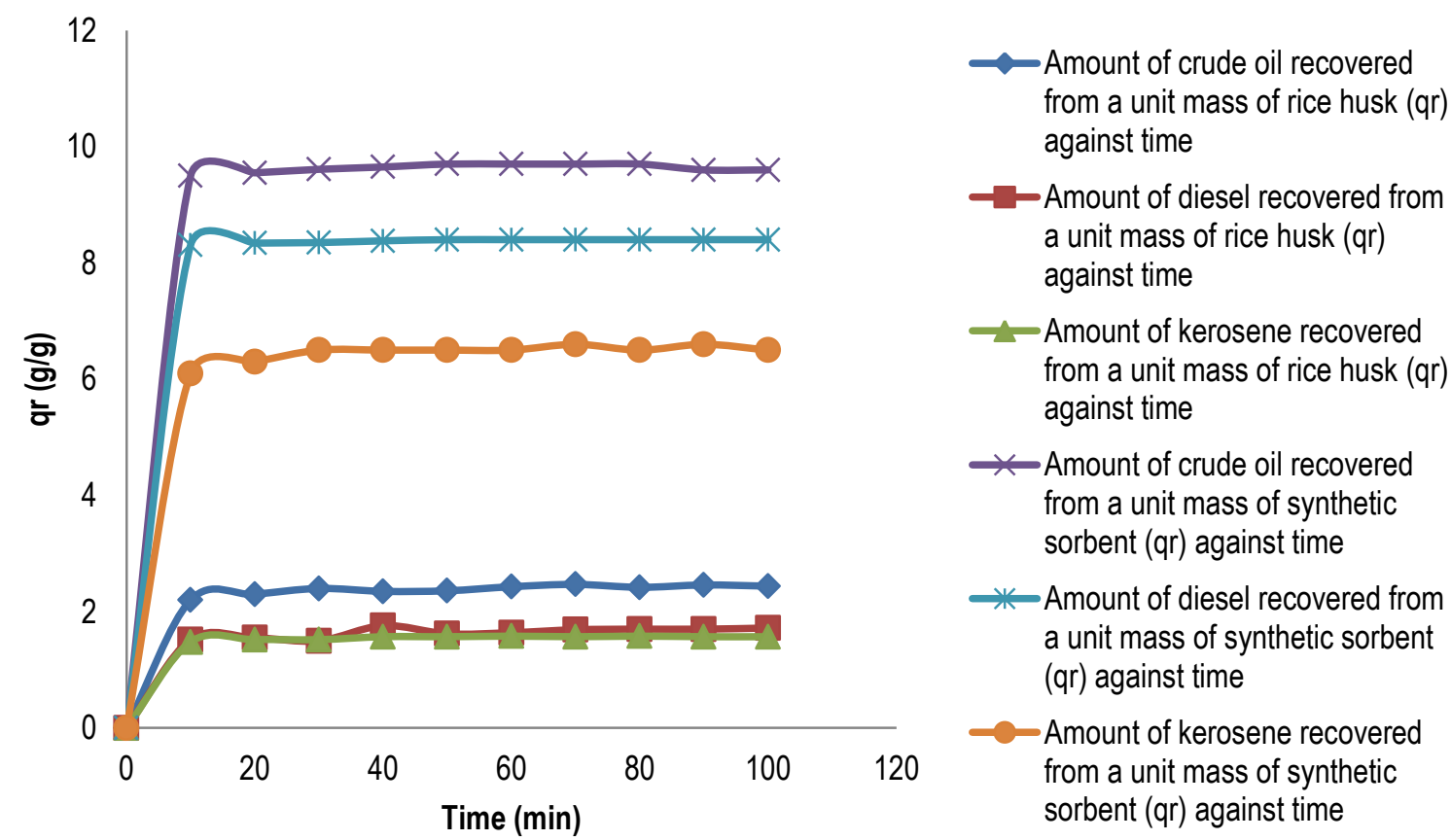

Figure 4: Amount of crude oil, diesel and kerosene recovered from a unit mass ofrice husk/synthetic sorbent against time.

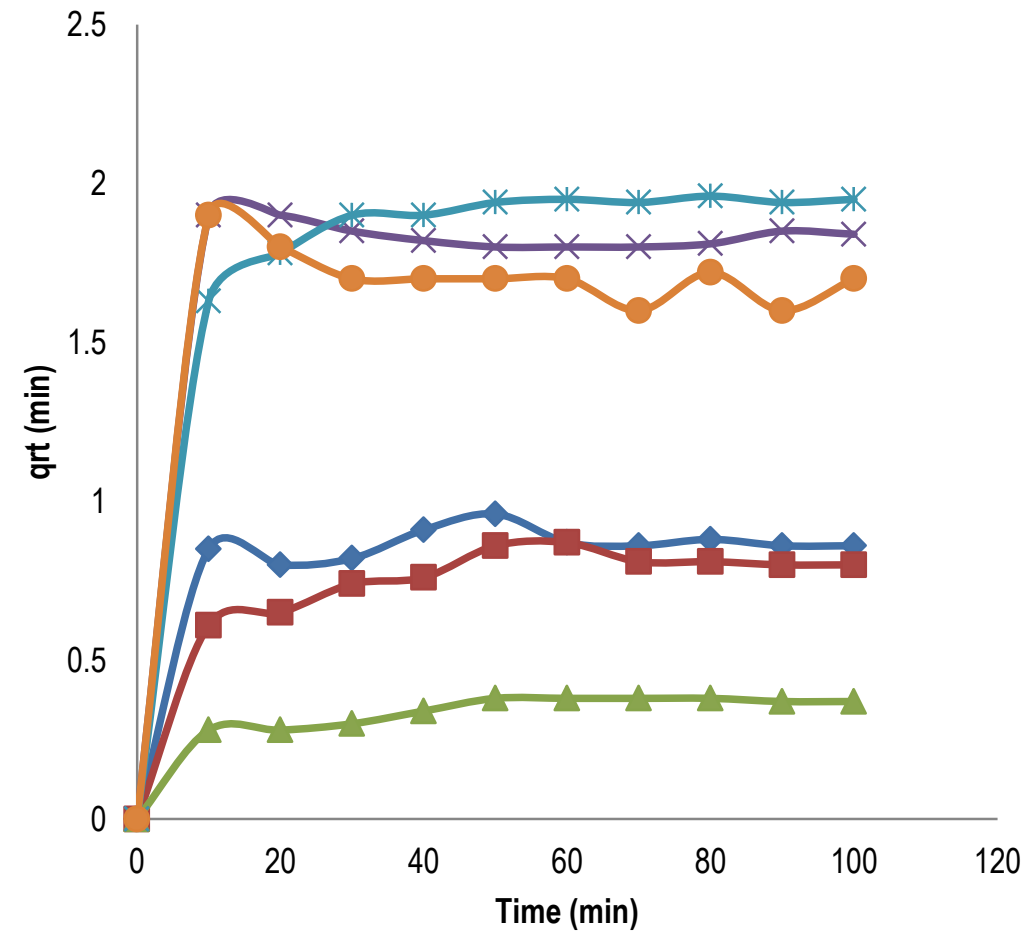

$\neg$ Amount of crude oil retained by a unit mass of rice husk (qrt) against time

$\rightarrow-$ Amount of diesel retained by a unit mass of rice husk (qrt) against time

- Amount of kerosene retained by a unit mass of rice husk (qrt) against time"

$\star$ Amount of crude oil retained by a unit mass of synthetic sorbent (qrt) against time

* Amount of diesel retained by a unit mass of synthetic sorbent (qrt) against time

-Amount of kerosene retained by a unit mass of synthetic sorbent (qrt) against time

Figure 5: Amount of crude oil, diesel and kerosene retained by a unit mass of rice husk/synthetic sorbent against time.

\section{Kinetic studies}

Table 2 presents the pseudo-first-order kinetic mode $R^{2}$ values of the sorption of the oils onto rice husk and synthetic sorbent mat. Except for synthetic mat sorption of kerosene, all other observed values were generally low. Moreover 
the calculated equilibrium adsorption capacities are lower than the experimental values implying the sorption of crude oil, diesel and keroseneonto rice husk and the synthetic sorbent is not a first order reaction.

The correlation coefficients $\left(R^{2}\right)$ and the calculated equilibrium adsorption capacities ( $q_{e}$ calc) values of the pseudo - second order kinetic model of the sorption of the oils onto rice husk and synthetic sorbent mat are presented in Table 3. The $R^{2}$ ranged from 0.999 to 1.00 , the straight line relationship was valid within the contact time, indicating that sorption of the oils onto the sorbents fits very well pseudo-second order kinetics. qecalcof each oil is higher than the experimental values, showing the fit of pseudosecond order mechanism for the sorption of crude oil, diesel and kerosene onto rice husk and synthetic sorbent mat. This indicates that when the oils get to the surface of the sorbents due to the driving force obtained from the high concentration of the oils, it encounters fewer active sites or functional groups on the surface to be adsorbed. The high concentration of the oils on the surface then pushes the adsorbed oils from the surface through the pores (intraparticle diffusion) to the internal sites of the adsorption. This implies that the adsorption process is more likely to conform to intraparticle diffusion mechanism.

The values of the intercepts of the intraparticle diffusion model are presented in Table 4. The values are low indicating that surface sorption did not contribute more to the rate-determining step. The $k_{d}$ constant was obtained from the slope of the plot of $q_{\mathrm{t}}$ as a function of $t^{1 / 2}$. Intraparticle diffusion is the rate-determining step when the plot is linear and passes through the origin (Dawodu and Akpomie, 2014). The plots produced non-zero interceptsand medium value of regression coefficient $\left(R^{2}\right)$ in both sorbents, implying that intraparticle diffusion mechanism was not the rate determining step, but, both intraparticle particle diffusion mechanismand liquid diffusion mechanism (surface sorption) were parts of the rate controlling steps of the sorption process.

Table 2: Pseudo - first order kinetic model (lagergren equation) for the sorption of crude oil, diesel and kerosene onto rice husk and standard.

\begin{tabular}{lllll}
\hline Oil type & $\mathrm{q}_{\text {exp }}(\mathrm{mg} / \mathrm{g})$ & $\mathrm{q}_{\mathrm{e}, \text { Calc }}(\mathrm{mg} / \mathrm{g})$ & $\mathrm{K}_{1}\left(\mathrm{~S}^{-1}\right)$ & $\mathrm{R}^{2}$ \\
\hline Crude oil (rice husk) & 3300 & 403.42 & 0.00083 & 0.9204 \\
$\begin{array}{l}\text { Diesel (rice husk) } \\
\text { Kerosene (rice husk) }\end{array}$ & 2500 & 1096.63 & 0.0015 & 0.8523 \\
$\begin{array}{l}\text { Crude oil (synthetic } \\
\text { sorbent) }\end{array}$ & 11500 & 221.40 & 0.0006 & 0.6128 \\
$\begin{array}{l}\text { Diesel } \\
\text { sorbent) }\end{array}$ & 121.51 & -0.0066 & 0.013 \\
Kerosene (synthetic & 10340 & & & \\
sorbent) & & 735.09 & -0.0009 & 0.8811 \\
\hline
\end{tabular}

Table 3: Pseudo - second order kinetic model (lagergren equation) for the sorption of crude oil, diesel and kerosene onto rice husk and standard

\begin{tabular}{llllll}
\hline Oil type & $q_{\text {eexp }}(\mathrm{mg} / \mathrm{g})$ & $\mathrm{q}_{\mathrm{e}, \text { Calc }}(\mathrm{mg} / \mathrm{g})$ & $\mathrm{K}_{1}\left(\mathrm{~S}^{-1}\right)$ & $\mathrm{R}^{2}$ & $\mathrm{~h}$ \\
\hline Crude oil (rice husk) & 3300 & 3333 & $9.0 \times 10^{-8}$ & 0.9973 & 0.99 \\
Diesel (rice husk) & 2500 & 2550 & $1.6 \times 10^{-6}$ & 0.999 & 1 \\
Kerosene (rice husk) & 1950 & 2020 & $2.5 \times 10^{-6}$ & 0.9995 & 1 \\
Crude oil (synthetic & 11500 & 12500 & $7.5 \times 10^{-8}$ & 1 & 1.18 \\
sorbent) & 10340 & 10880 & $8.1 \times 10^{-8}$ & 1 & 0.99 \\
Diesel (synthetic & 8200 & 8333.33 & $1.4 \times 10^{-7}$ & 1 & 0.99 \\
sorbent) & & & & & \\
Kerosene(synthetic & & & & & \\
sorbent) & & & & & \\
\hline
\end{tabular}


The deviation from the origin is due to the difference in mass transfer between the initial and final stages of the sorption process (Das, 2011). For the liquid film diffusion kinetics, a plot of $\ln (1-F)$ as a function of $t$ with a zero intercept would suggest that the kinetics of the sorption process are controlled by diffusion through the liquid film surface surrounding the solid sorbent. Non-zero intercepts and moderate regression coefficients $\left(R^{2}\right)$ were obtained for both sorbents (Table 4). This indicates that liquid film diffusion (surface sorption) was not the rate determining step, but was part of the rate determining step for the sorption process.

Environment applicability of crude oil, diesel and kerosene displaced on water, onto rice husk/synthetic sorbent mat. The amount of water sorbed together with each sorbate onto rice husk and synthetic sorbent mat in the experiment to determine suitable environment applicability of rice husk and the standard was 5 $\mathrm{ml}(1.16 \mathrm{~g})$ for rice husk and $6 \mathrm{ml}(1.2 \mathrm{~g})$ for the standard. These amounts are minimal for each of the sorbent, indicating that rice husk can be employed to mop oil spill on water.

Table 4: Intraparticle diffusion and liquid film diffusion for the sorption of crude oil, diesel and kerosene onto rice husk and standard

\begin{tabular}{|c|c|c|c|c|}
\hline Oil type & $\begin{array}{c}\text { Intraparticle } \\
\text { diffusion } \mathrm{K}_{\mathrm{d}}(\text { meq g-1 } \\
\left.\mathrm{S}^{1 / 2}\right)\end{array}$ & $\begin{array}{c}\text { Intraparticle } \\
\text { diffusion } \\
\mathrm{R}^{2}\end{array}$ & C & $\begin{array}{l}\text { Liquid film } \\
\text { diffusion } \\
\text { R2 }^{2}\end{array}$ \\
\hline \multirow{8}{*}{ 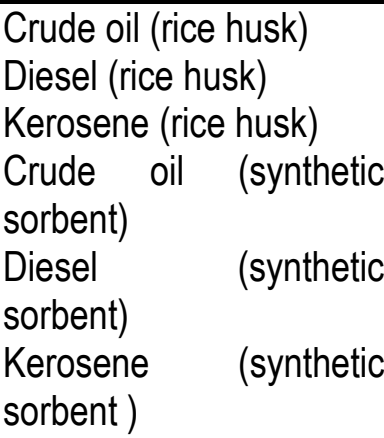 } & 0.0077 & 0.7751 & -3560 & 0.7987 \\
\hline & 0.0016 & 0.7668 & & \\
\hline & 0.0014 & 0.7751 & -2330 & 0.8486 \\
\hline & 8.82 & 0.0236 & & \\
\hline & 9.06 & $0-4$ E05 & -2270 & 0.8486 \\
\hline & 9.85 & 0.6164 & & \\
\hline & & & -1143 & 0 \\
\hline & & & -10100 & 0.7526 \\
\hline & & & -8100 & 1.00 \\
\hline
\end{tabular}

\section{CONCLUSION}

Rice husk has lower oil sorption capacity and sorbed oil recoverability than the standard (synthetic sorbent mat). However, rice husk has the ability to retain sorbed oil which makes it a good sorbent when oil recovery is not required. The sorption of crude oil, diesel and kerosene onto rice husk and the standard follows Langmuir adsorption model, and pseudo second order kenetics. Intraparticle diffusion and liquid film diffusion model were aspects of the rate determining steps of the sorption process of the oils onto rice husk and the standard.

\section{REFERENCES}

Brown, G.I. (1983). Introduction to Physical Chemistry. $2^{\text {nd }}$ Edition. Longman, London, Pp 337 - 338.

Choi, H. and Cloud, R.N. (1992). Natural sorbents in oil spill cleanup. Environmental Science and Technology. 26(4): 772 -776.

Das, B. and Mondal, N. K. (2011).Calcerous soil as a new adsorbent to remove lead fromaqueous solution: equilibrium, kinetic and thermodynamic study. Universal Journal of Environmental Research and Technology,1(4): 515530.

Dawodu, F. A. andAkpomie, K. G.(2014). Simultaneous adsorption of $\mathrm{Ni}(\mathrm{II})$ and $\mathrm{Mn}(\mathrm{II})$ ions from aqueous solution unto 
a Nigerian kaolinite clay. Journal of Materials research and technology, 3(2): 129-141.

Deschamps, G., Caruel, H.,Borredon, M.E., Bonnin, C., Vignoles, C. (2003).Oil removal from water by selective sorption properties and comparison with other cotton fibre-based sorbents. Environmental Science and Technology, 37(5):1013-1015.

Dong, T., Xu, G., and Wang, F. (2015). Oil spill cleanup by structured natural sorbents made from cattail fibers. Industrial Crops and Products, 76(15): 25-33.

Elovich, S. Y. (1962). Theory of adsorption from solutions of non-electrolytes on solid (I) equation adsorption from solutions and the analysis of its simplest form, (II) verification of the of adsorption isotherm from solutions. Izvestila Akademii Nauk, 2: 209-216.

FAO Statistical Yearbook (2013).Food and Agriculture Organisation of the United Nations, Rome, Pp 132.

Faust, D. C. and Aly, M. O. (1983). Chemistry of wastewater treatment.1st Edition. Butterworth,London, P 251.

Fingas, M. (2010).Oil spill science and technology.1st Edition.Gulf Professional Publishing, Boston, Pp1147 - 1148.

Freundlich, H.M.F. (1906). Uber die adsorption inlosungen. Zeitschrift Fur Physikalische Chemie. 57: 385- 470 :In Hamdaoui, $O$. andNaffrechoux, E. (2007). Modelling of adsorption isotherms of Phenoland chlorophenols onto granular activated carbon Part 1.Two-parameter models and equations allowing determination of thermodynamic parameters. Journal of Hazardous Material, 17(147):381-394.

Gerard, M.C. (2016). Fossil fuels: current status and future directions. 1 $^{\text {stE }}$ Edition. World Scientific Publishing Company. New Jersey, Pp 123-124.

Hamdaoui. $O$ and Naffrechoux, E. (2007). Modelling of adsorption isotherms of phenol and chlorophenols onto granular activated carbon Part 1. TwoParameter models and equations allowing determination of thermodynamic parameters. Journal of Hazardous Materials, 17(147):381-394.

Hester, M. V., Willis, J. M., Rouhani, S., Steinhoff, M. A. and Baker, M, C. (2016). Impacts of theDeepwater Horizon oil spill on the salt marsh vegetation of Louisiana. Environmental Pollution, 216: 361-376.

Ho, Y. S. and Mackay, G. (1998). The kinetics of sorption of basic dyes from aqueous solution by sphagnum moss peat. The Canadian Journal of Chemical Engineering, 76(4): 822-827.

Igwe, J.C. andAbia, A.A. (2007). Adsorption Isotherm Studies of $\mathrm{Cd}$ (II), $\mathrm{Pb}$ (II) and $\mathrm{Zn} \mathrm{(II)} \mathrm{ions} \mathrm{bioremediation} \mathrm{from}$ aqueous solution using unmodified and EDTA-modifiedmaize cob. Ecletica Quimica, 32(1):33-41.

Jing, H., Song, H., Liang, Z., Fuxing, G. and Yuhshan, H. (2010).Equilibrium and thermodynamic parameters of adsorption of methylene blue onto rectorite. Fresenius Environmental Bulletin, 19(11a):2651-2656.

Kadafar, A.Y. (2012). Oil exploration and spillage in the Niger Delta of Nigeria. Civil and Environmental Research, 2(3):38-51.

Kent, J. A. (2010). Kent and Riegel's handbook of industrial chemistry and biotechnology. $11^{\text {th }}$ Edition.Springer, New York, p 802.

Langmuir, I. (1916). The constitution and fundamental properties of solids and liquids. Journal of American Chemical Society, 38:2221- 2295. In: Hamdaoui, O. andNaffrechoux, E. (2007). Modelling of adsorption isotherms of phenol and chlorophenols onto granular activated carbon Part 1.Twoparameter models and equations allowing determination of thermodynamic parameters. Journal of Hazardous Materials, 17(147):381-394.

Lim, T. T. and Huang, X. (2007).Evaluation of kapok (ceibapentandra (L.)Gaertn) as a natural hollow hydrophobic - oleophilic fibrous sorbent for oil spill 
cleanup.Chermosphere. 66 (5): 955 963.

Mansaray, K. G. and Ghally, A. E. (1997). Physical and thermochemical properties of rice husk. Energy Sources, 19(9):989-1004.

Nduka, J.K., Ezenweke, L., Ezenwa, E.T.(2008). Comparison of the mopping ability ofchemically modified and unmodified biological wastes on crude oil and its lower fractions. Bioresource Technology, 99(16): 7902 - 7905.

Omatola, K. M. and Onojah, A. D. (2009).Elemental analysis of rice husk ash using $\mathrm{x}$-rayflourescence technique.International Journal of Physical Sciences. 4(4): 189 - 193.

Paulauskiene, T., Jucike, I.,Juscenko, N. and Baziuke, D. (2014). The use of natural sorbents for spilled crude oil and diesel cleanup from the water surface. Water, Air \& Soil Pollution, 225:1959.

Piccin, J.S., Dotto, G.L. andPinto, L .A.A. (2011). Adsorption isotherms and thermochemical data of FD\&C red $n^{\circ}$ 40 binding by chitosan. Brazilian Journal of Chemical Engineering, 28 (2):1-6.

Siddique, R. (2008). Waste materials and byproducts in concrete.1 ${ }^{\text {st }}$ Edition.Springer-Verlag, Berlin, Pp235 $-236$.

Taffarel, S. R. andRubio, J.(2009).On the removal of $\mathrm{Mn}(\mathrm{II})$ ions by adsorption onto natural and activated Chilean zeolites. Minerals Engineering.22(4): 336-343.

Testa, S. M. and Jacobs, J. A. (2013).Oils spills and gas leaks: environmental response, prevention and cost recovery.1st Edition, Mcgraw Hill Education, Pennsylvania, Pp 7 -13.
Thisday, $\quad$ August 2017. https://www.thisdaylive.com/index.php/ 2017/08/08

Venn-Watson, S., Colegrove, K. M.,Litz J., Kinsel, M., Terio, K., Saliki, J., Fire, S., Carmichael, C. C., Hatchett, W., Pitchford, J. and Tumlin, M. (2015). Adrenal glandand lung lesions in Gulf of Mexico common bottlenose dolphins (tursiopstruncatus) found dead following the deepwater horizon oil spill. PLoS One. 10(5):e0126538.

Volesky, B. V. (2004). Sorption and biosorption.Ist Edition. BV Sorbex, Montreal, Pp $103-130$.

Wang, A. (2014). The science of an oil spill. $1^{\text {st }}$ Edition.Cherry Lake Publishing, Michigan, p 14.

Weber, W. J. and Morris, J. C.(1963).Kinetics of adsorption of carbon from solution.Journal

SanitaryEnginering.Division

American.Society of Civil Engineering. 89: 31-60.

Wei-Hong, X.,Lei, W.,Jing, W.,Guo-Ping, S., JinHuai, L., Han-Qing, Y.,Xing-Jiu, $H$. (2013).Superparamagneticmesoporous ferrite nanocrystal clusters for efficient removal of arsenite from water. CrystEngComm 15(39):7805-7903.

Wener, W.J., McGinley, P.M. and Katz, I.E. (1991). Sorption phenomena in subsurfacesystems: concepts, models and effects on contaminant fate and transport. Water Resources, 25(5):499528. 